\title{
Clopidogrel Resistance: Current Issues
}

\author{
N. S. Neki ${ }^{1}$ \\ Received: July 12, 2015 Accepted: December 26, 2015 \\ doi: http://dx.doi.org/10.3329/jemc.v6i1.26381
}

\begin{abstract}
Antiplatelet agents are mainly used in the prevention and management of atherothrombotic complications. Dual antiplatelet therapy, combining aspirin and clopidogrel, is the standard care for patients having acute coronary syndromes or undergoing percutaneous coronary intervention according to the current ACC/AHA and ESC guidelines. But in spite of administration of dual antiplatelet therapy, some patients develop recurrent cardiovascular ischemic events especially stent thrombosis which is a serious clinical problem. Antiplatelet response to clopidogrel varies widely among patients based on ex vivo platelet function measurements. Clopidogrel is an effective inhibitor of platelet activation and aggregation due to its selective and irreversible blockade of the P2Y12 receptor. Patients who display little attenuation of platelet reactivity with clopidogrel therapy are labeled as low or nonresponders or clopidogrel resistant. The mechanism of clopidogrel resistance remains incompletely defined but there are certain clinical, cellular and genetic factors including polymorphisms responsible for therapeutic failure. Currently there is no standardized or widely accepted definition of clopidogrel resistance. The future may soon be realised in the routine measurement of platelet activity in the same way that blood pressure, cholesterol and blood sugar are followed to help guide the therapy, thus improving the care for millions of people. This review focuses on the methods used to identify patients with clopidogrel resistance, the underlying mechanisms, metabolism, clinical significance and current therapeutic strategies to overcome clopidogrel resistance.
\end{abstract}

Key words: Acute coronary syndrome; Percutaneous coronary intervention; Clopidogrel; Platelet aggregation

J Enam Med Col 2016; 6(1): 38-46

\section{Introduction}

Oral antiplatelet agents are the cornerstone of modern pharmacotherapy in the prevention and management of cardiovascular atherothrombotic diseases according to the current ACC/AHA and ESC guidelines. ${ }^{1,2}$ It is well-established that the antiplatelet response to clopidogrel is not uniform and it varies widely among patients $^{3,4}$ and it reflects failure of clopidogrel to achieve its anti-aggregatory effect. When combined with aspirin, clopidogrel is the gold standard for the prevention of subacute stent thrombosis (SAT) in subjects undergoing PCI and thus reducing major adverse cardiovascular events in patients with non-ST segment elevation acute coronary syndromes. ${ }^{5}$ This article discusses the definition, detection, risk factors and clinical consequences of clopidogrel resistance and role of current therapeutic strategies to overcome clopidogrel resistance.

\section{Platelet aggregation}

Platelets adhere to the sites of vascular injury. Adenosine diphosphate (ADP) plays an important role in the platelet activation and aggregation. ${ }^{6}$ As a result of damaged or disrupted endothelium, circulating platelets adhere to the vessel wall through interactions with von Willebrand factor, collagen, fibronectin, vitronectin, laminin etc. ${ }^{7}$ After activation, platelets

1. Professor, Department of Medicine, Government Medical College, Amritsar, India and Visiting Professor, Institute of Cardiovascular Sciences, University of Minnitoba, Winnipeg, Canada

Correspondence N. S. Neki, Email: drneki123@gmail.com 
release secondary agonists like thromboxane A2 and ADP or lead to the thrombin formation locally as a result of coagulation cascade. ${ }^{8}$ Additionally platelets aggregate to the adherent platelet layer through cross linking of fibrinogen to adjacent platelets creating a platelet mass which acts as a scaffold for coagulation. ${ }^{9}$ ADP binds to neighboring platelets through two Gprotein-coupled receptors (P2Y1 and $\mathrm{P} 2 \mathrm{Y} 2)$ and the cation channel coupled $\mathrm{P} 2 \mathrm{X} 1$ receptor. ADP-induced platelet aggregation occurs as a result of stimulation of both $\mathrm{P} 2 \mathrm{Y} 1$ and $\mathrm{P} 2 \mathrm{Y} 2$ receptors. ${ }^{10}$ Activated and degranulated platelets expose glycoprotein (GP) IIb/IIIa receptors at their surface thereby allowing fibrinogen binding. Thus platelets activation occurs as a result of formation of bridges between adjacent activated platelets. $^{11}$

\section{Pharmacokinetics of clopidogrel}

Clopidogrel is an ADP receptor antagonist like all thioenopyridines and is an inactive prodrug. It requires oxidation by the hepatic cytochrome P450 (CYP 450) to generate an active thiol metabolite. ${ }^{12}$ Esterases hydrolyze clopidogrel into an inactive carboxylic acid derivative which constitutes $85 \%$ of clopidogrel-related circulating compounds. CYP $3 \mathrm{~A} 4$ and CYP3A5 are the enzymes responsible for the oxidation of the thiophene ring of clopidogrel to 2-oxoclopidogrel which is further oxidized and ultimately leads to formation of carboxyl and thiol group. ${ }^{12}$ The thiol group forms a disulfide bridge with two extracellular cysteine residues located on the platelet surfaces and this causes irreversible ADP blockade. ${ }^{13}$ Many studies have documented that CYP2C19 genotyping detects more than $90 \%$ of poor clopidogrel metabolizers. ${ }^{14,15}$ The carriers of CYP2C19 3 and 4 alleles may also result in no enzymatic activity in the same way as CYP2C19 2. ${ }^{16}$ Polymorphisms in careers of CYP2C9 gene ${ }^{15,17}$ may be responsible for reduced clopidogrel metabolism. The existence of CYP2C19 polymorphisms may be responsible for increased cardiovascular events and all cause mortality as shown in various studies. ${ }^{18,19} \mathrm{~A}$ standard dose of clopidogrel will achieve P2Y12 antagonism, which translates into about $50 \%$ of the inhibitors of ADP-induced platelet aggregation. ${ }^{20}$ In healthy subjects platelet inhibition is dose-related up to a single dose of $400 \mathrm{mg}$ with no further increase with $1600 \mathrm{mg} .{ }^{21}$ The maximum inhibition achieved with a single $400 \mathrm{mg}$ dose takes 2 to 5 hours while a daily dose of $75 \mathrm{mg}$ takes 3-7 days to reach the same level of inhibition. ${ }^{22}$ Clopidogrel also attenuates plateletleukocyte aggregate formation, levels of CRP, P selectin, CD40L and the rate of thrombin formation. $^{23,24}$

\section{Mechanisms of clopidogrel resistance}

\section{Drug-drug interactions}

In a study by Gilard et $\mathrm{al}^{25}$ it has been shown that omeprazole as proton pump inhibitor (PPI) decreased the clinical efficacy of clopidogrel using the vasodilator-stimulated phosphoprotein (VASP) method. Cuisset et $\mathrm{al}^{26}$ in their study involving subjects who underwent coronary stenting for non-ST elevation ACS have shown that the number of clopidogrel nonresponders in the omeprazole group was more as compared to pantoprazole group. Both clopidogrel and PPIs are metabolized by the same CYP 450 pathway but the diminished biological effect of clopidogrel may be due to competitive effect of PPI on the CYP2C19 enzyme. ${ }^{27}$ COGENT trial involving randomized 3627 patients with ACS and/or stent placement on clopidogrel found that omeprazole group had few gastrointestinal events unlike the placebo group. ${ }^{28}$ Previously statins have been shown to reduce clopidogrel's efficacy possibly due to the common sharing CYP3A4 enzymatic pathway between clopidogrel and statins. ${ }^{29}$ But recent studies have shown that use of statins with high dose clopidogrel $(600 \mathrm{mg})$ is safe. ${ }^{30,31}$ Gurbel et al ${ }^{32}$ have demonstrated that decreased response to clopidogrel may occur with high dose of calcium channel blockers and angiotensin converting enzyme inhibitors.

\section{Definition of clopidogrel resistance}

Clopidogrel resistance is a phenomenon encountered in daily medical practice. In its broadest sense, resistance refers to the continued chance of ischemic events despite adequate clopidogrel therapy and compliance (ie, P2Y2 receptors of the platelet). ${ }^{33}$ However, the term nonresponders seems more appropriate given the fact that patients retain a degree of response to the medical treatment. Other terms have been used to describe patients with ineffective platelet inhibition by clopidogrel as hyporesponsive, non-responsive and semi-responsive. ${ }^{34,35}$ 
The prevalence of clopidogrel nonresponse in patients varies between 4-30\% among different populations 24 hours after administration. ${ }^{36}$ The reported rates vary depending upon the different tests used to measure the extent of ADP-induced platelet aggregation and the presence of factors contributing to greater baseline platelet reactivity.

Potential mechanisms of clopidogrel resistance are as follows ${ }^{37}$ :

\section{Extrinsic mechanisms}

1. Patient non-compliance

2. Underdosing or inappropriate dosing of clopidogrel

3. Drug-drug interaction involving CYP3A4

II. Intrinsic mechanisms

1. Genetic variables

(a) Polymorphisms of $\mathrm{P} 2 \mathrm{Y} 12$ receptors

(b) Polymorphisms of CYP3A5

2. Increased release of ADP

3. Alternative pathways of platelet activation

(a) Failure to inhibit catecholamine-mediated platelet activation (epinephrine)

(b) Up-regulation of P2Y12 - independent pathways (thrombin, thromboxin A2, collagen).

High pretreatment platelet reactivity and thrombotic burden may cause diminished response to clopidogrel therapy because these patients remain the most reactive during the first five days of clopidogrel treatment. Overweight and obesity are also associated with lower clopidogrel platelet effect. ${ }^{38}$ But the limitation of this study was small size of sample and nonrandomized study design. So, these data need to be confirmed further with large scale studies.

\section{Laboratory methods to measure clopidogrel resistance}

Various laboratory methods to measure clopidogrel resistance have been demonstrated to assess ADPinduced platelet function such as turbidometric aggregation, flow cytometry to measure p-selectin and activated GP IIb/IIIa expression and vasodilatorstimulated phosphoprotein phosphorylation levels and point of care methods. Now R P2Y12 assay, platelet mapping with thromboelastography and multiplate analyzer are used. ${ }^{39-41}$ As clopidogrel induces platelet disaggregation, the response to clopidogrel would be better shown by measuring late platelet aggregation at six minutes after stimulation with ADP rather than maximum aggregation. ${ }^{42}$ The phosphorylation state of vasodilator-stimulated phosphoprotein is a specific intracellular marker of residual P2Y12 receptor reactivity in patients treated with clopidogrel and this technique is the most specific indicator of residual P2Y12 activity in patients treated with a P2Y12 inhibitor. $^{43}$

The phosphorylation of VASP is stimulated by the prostaglandin (PGE1) via the increase in platelet cAMP level leading to increase in platelet cAMP level. However, ADP inhibits PGE1-stimulated VASP phosphorylation by lowering the cAMP level through its effects on the $\mathrm{P} 2 \mathrm{Y} 12$ receptors. Clopidogrel does not alter the basal and PGE1-stimulated VASP phosphorylation but strongly attenuates the inhibitory effect of ADP on PGE1-stimulated VASP phosphorylation. ${ }^{44}$

\section{Clinical relevance of clopidogrel responsiveness}

Many studies have demonstrated that inadequate platelet inhibition leads to adverse clinical outcomes including recurrent ischemic cardiovascular events, stent thrombosis and periprocedural myocardial infarction. These studies have been done in different subgroups of patients undergoing PCI for ST elevation myocardial infarction (STEMI) or non-STEMI as well as elective PCI procedures, as documented in Table I.

\section{Management of clopidogrel resistance}

There is a clearcut relationship between failed clopidogrel therapy and cardiovascular events. Clinical approaches to overcome clopidogrel resistance have not yet been defined. However, different methods have been employed to overcome low response to clopidogrel. These include higher loading and/or maintenance dose or switching over to other antiplatelet drugs. An initial approach should be to correct the clinical factors responsible for resistance, ensuring proper patient compliance, to avoid or minimize drugdrug interactions and to achieve optional control of glucose and cholesterol level. 
Table I: Overview of studies analyzing clinical outcomes of clopidogrel resistance

\begin{tabular}{|c|c|c|c|c|}
\hline Study & Number & Population & Results & Clinical relevance \\
\hline 45 & 60 & $\begin{array}{l}\text { Primary PCI for } \\
\text { STEMI }\end{array}$ & $\begin{array}{l}\uparrow \text { ADP-induced platelet } \\
\text { aggregation (4th quartile) }\end{array}$ & $\begin{array}{l}\text { Recurrent cardiovascular } \\
\text { events }\end{array}$ \\
\hline 46 & 106 & PCI for NSTEMI & $\uparrow$ platelet aggregation & Recurrent cardiac events \\
\hline 47 & 192 & Non-emergent PCI & $\begin{array}{l}\uparrow \text { periprocedural platelet } \\
\text { aggregation }\end{array}$ & $\begin{array}{l}\text { Post-PCI ischemic events } \\
\text { (6 months) }\end{array}$ \\
\hline 48 & 100 & Non-emergent PCI & $\begin{array}{l}\uparrow \text { Periprocedural platelet } \\
\text { aggregation in patients on } \\
\text { chronic clopidogrel }\end{array}$ & $\begin{array}{l}\text { Post-PCI ischemic events } \\
\text { (6 months) }\end{array}$ \\
\hline 49 & 802 & Elective PCI & $\begin{array}{l}\uparrow \text { Periprocedural platelet } \\
\text { aggregation }\end{array}$ & $\begin{array}{l}\text { MACE distribution in the } \\
\text { quartiles }\end{array}$ \\
\hline 50 & 36 & Monitoring of VASP & $\begin{array}{l}\uparrow \mathrm{P} 2 \mathrm{Y} 12 \text { reactivity ratio } \\
\text { (VASP levels) }\end{array}$ & Stent thrombosis \\
\hline 51 & 120 & & $\begin{array}{l}\uparrow \mathrm{P} 2 \mathrm{Y} 12 \text { reactivity ratio, } \\
\text { platelet-stimulated } \\
\text { GP2b/3a } \\
\text { clopidogrel/ } \\
\text { aspirin resistant patients }\end{array}$ & Stent thrombosis \\
\hline 52 & 120 & Elective PCI & $\begin{array}{l}\uparrow \text { clopidogrel/aspirin resistant } \\
\text { patients }\end{array}$ & $\begin{array}{l}\text { Post PCI myocardial } \\
\text { necrosis }\end{array}$ \\
\hline 53 & 49 & & $\begin{array}{l}\uparrow \text { shear-induced platelet } \\
\text { aggregation }\end{array}$ & Stent thrombosis \\
\hline 54 & 683 & PCI for ACS & $\begin{array}{l}\uparrow \text { ADP-induced platelet } \\
\text { aggregation }\end{array}$ & Stent thrombosis \\
\hline 55 & 380 & PCI with DES & $\begin{array}{l}\uparrow \mathrm{ADP}-\text { induced platelet } \\
\text { reactivity }\end{array}$ & Stent thrombosis \\
\hline 56 & 160 & $\begin{array}{l}\text { PCI (STEMI } \\
\text { excluded) }\end{array}$ & $\uparrow$ & Cardiac events \\
\hline
\end{tabular}

\section{Higher doses}

In recent clinical studies of patients undergoing PCI, a loading dose of $600 \mathrm{mg}$ clopidogrel was associated with a higher level of platelet inhibition, which means lower post-treatment reactivity to ADP and a lower incidence of nonresponsiveness when compared to 300 mg dose. ${ }^{57-60}$ Kastrati et al $^{61}$ in their study found that patient achieved additional platelet inhibition when a $75 \mathrm{mg}$ /day clopidogrel maintainence dose was followed by an additional $600 \mathrm{mg}$ loading dose. In the CLEAR PLATELET study ${ }^{51}, 600 \mathrm{mg}$ loading dose showed a superior pharmacodynamic antiplatelet profile as compared to $300 \mathrm{mg}$ clopidogrel loading dose. In the
ISAR-CHOICE study ${ }^{13}$, there was no additional effect regarding clopidogrel metabolite levels and platelet inhibition between the 600-900 mg loading dose possibly because of intestinal absorption concerned with response variability. So the $600 \mathrm{mg}$ doses appear to achieve maximum inhibition more rapidly than 300 mg dose. Thus higher loading dose may be considered for selected patient showing high platelet reactivity to ADP. However the current ACC/AHA guidelines for PCI provide a class IIa recommendation that 'a regimen of greater than $300 \mathrm{mg}$ is reasonable to achieve higher levels of antiplatelet activity more rapidly'. Finally the ACC/AHA guidelines for PCI provide a class IIb 
recommendation that in patient whom subacute thrombosis may be lethal, platelet aggregation studies may be considered and dose of clopidogrel increased to $150 \mathrm{mg} /$ day if less than $50 \%$ inhibition of platelet aggregation is exhibited. ${ }^{62}$ However, the later guidelines do not support the cutpoint of $50 \%$ inhibition. But Bonello et $\mathrm{al}^{63}$ in their study involving $600 \mathrm{mg}$ loading dose of clopidogrel found better clinical outcome in post-PCI patients where clopidogrel resistance and the platelet monitoring were done by vasodilator-stimulated phosphoprotein (VASP). But in the GRAVITUS trial ${ }^{64}$ done in PCI with drug eluting stents, clopidogrel resistant patients did not show any superiorty of $150 \mathrm{mg}$ over $75 \mathrm{mg}$ of clopidogrel. But the ALBION study ${ }^{65}$ has also shown the superiorty of loading dose of clopidogrel in the clopidogrel resistant patients. In the ARMYDA-4 study ${ }^{66}$, reloading with $600 \mathrm{mg}$ clopidogrel pre-PCI did not offer any additional benefit in patients on chronic clopidogrel therapy. In the ARMYDA-5 study ${ }^{67}$, which compared clopidogrel loading with $600 \mathrm{mg}$ 'in lab' vs $4-8$ hours pre-PCI, did not show any significant difference between the two groups.

\section{Thioenopyridine agents}

Other medications such as prasugrel, cangrelor, ticagrelor, cilostazole, AZ D6140 are also available for the treatment in clopidogrel resistance for ACS.

a) Prasugrel: It is a prodrug and irreversible inhibitor of P2Y12 with a rapid onset of action and produces more potent receptor blockade. It is mainly metabolized by cytochrome enzyme CYP3A and CYP2B6, lesser metabolized by CYP2C9 and CYP2C19. ${ }^{68,69}$ Inhibitor of platelet aggregation has been shown to be more rapid with prasugrel with the lesser incidence of nonresponders, compared with the standard clopidogrel dose of $75 \mathrm{mg}^{70}$ Wivott et $\mathrm{al}^{64}$ in their study involving 201 post-PCI patients has shown that prasugrel in loading dose (LD) of $60 \mathrm{mg}$ and $10 \mathrm{mg}$ maintenance dose (MD) achieved higher and more consistent level of platelet inhibition than clopidogrel at $600 \mathrm{mg}$ LD and $150 \mathrm{mg}$ MD. The ACAPULCO study ${ }^{71}$ has shown the superiorty of prasugrel in platelet inhibition compared to high dose clopidogrel $900 \mathrm{mg} \mathrm{LD}$ or $150 \mathrm{mg}$ MD. In the JUMBO-T1M1-26 trail $^{72}$, prasugrel treatment was associated with primary endpoint of regimen and bleeding events were the same for all doses of prasugrel. In the TRITION-T1M138 study $^{73}$, clinical outcome in terms of cardiovascular death, myocardial infarction and stroke were better with prasugrel compared with clopidogrel.

b) Cangrelor: It is a nonthioenopyridine P2Y12 inhibitor given intravenously to overcome clopidogrel resistance. ${ }^{74}$ It has greater platelet inhibition than clopidogrel, rapid onset of action, short plasma half-life and is not activated by hepatic p450 cytochrome system and is a direct antagonist of $\mathrm{P} 2 \mathrm{Y} 12$ receptor. ${ }^{75}$

c) Cilostazole: It is a potent inhibitor of phosphodiesterase (PDE), targeting both platelets and vascular smooth muscle cells. It is found more potent than standard dose clopidogrel in studies using the Verify Now Assay. ${ }^{76}$ ACCELRESISTABCE study ${ }^{77}$ has shown that addition of cilostazole to standard clopidogrel proves more effective for platelet inhibition as compared to high maintenance dose of clopidogrel (150 mg/day). So cilostazole can be used in clopidogrel resistance.

d) Ticagrelor: It targets ADP receptors P2Y12. But unlike clopidogrel and prasugrel, the receptor inhibition is reversible. ${ }^{78}$ The PLATO trial ${ }^{79}$ involving 18624 patients with acute coronary syndrome taking ticagrelor $(180 \mathrm{mg}$ loading dose, $90 \mathrm{mg}$ twice daily thereafter orally) and clopidogrel (300-600 mg loading dose, $75 \mathrm{mg}$ daily thereafter) has shown that cardiovascular events were significantly low in the ticagrelor group but there was higher rate of major bleeding which was not related to coronary artery bypass grafting.

Various studies ${ }^{80,81}$ have failed to show the superiority of cangrelor over clopidogrel. There is need for further studies to prove the superiority of cangrelor in order to overcome clopidogrel resistance.

\section{Conclusion}

The use of clopidogrel has tremendously increased over the last few years, following its effectiveness together with aspirin in greatly reducing clinical adverse events in patients having acute coronary syndrome or undergoing PCI. There is no doubt that the laboratory phenomenon of "resistance" to clopidogrel exists. 
There are many tests to assess platelet reactivity and these have shown a large variability in the response to clopidogrel therapy. Different methods report different prevalences depending upon the tests used, the cut-off value used to define resistance, the timing with respect to medication and population group studied. None of the methods used to assess platelet function fulfils the ideal criteria. There is a need to have a simple affordable, near-patient test useful in the clinical (not just laboratory) setting which should be validated in a large clinical trial in order to identify patients having clopidogrel resistance. However, use of higher loading or maintenance doses of clopidogrel or new and more potent P2Y12 receptor blockers is a potential alternative strategy although potential beneficial effects need to be balanced with an increased risk of bleeding. In addition to other factors, genetic polymorphisms and the patient risk profile should also be taken into account to detect clopidogrel resistance. Combined appropriate antiplatelet therapies may be required for the pharmacologic management of patients of high risk for arterial thrombotic events but not as a primary prevention modality or as an alternative to anticoagulants.

\section{References}

1. Kushner FG, Hand M, Smith SC Jr., King SB, Anderson JL, Antman EM et al. Focussed updates: ACC/AHA Guidelines for the management of patients with STelevation myocardial infarction (updating the 2004 Guideline and 2007 Focussed update). A report of the American College of Cardiology Foundation/American Heart Association Task Force on Practice Guidelines. Circulation 2009; 120: 2271-2306.

2. Vande Werf F, Bax Jeletreact A,Falk V, Crea F, Huber K et al. Management of acute myocardial infarction in patients presenting with persistent ST segment elevation: the Task Force on the management of ST segment elevation of acute myocardial infarction of the European Society of Cardiology. Eur Heart J 2008; 29: 2909-2945.

3. Dupont AG, Gabriel DA, Cohen MG. Antiplatelet therapies and the role of antiplatelet resistance in acute coronary syndrome. Thromb Res 2009; 124: 6-13.

4. Jaremo P, Lindahi TL, Fransson SG, Richter A. Individual variations of platelet inhibition after loading doses of clopidogrel. J Intern Med 2002; 252: 233-238.

5. Yusuf S, Zhao F, Mehta SR, Tognoni G, Anand S, Awan N et al. Effects of clopidogrel in addition to aspirin in patients with acute coronary syndromes without ST-segment elevation. N Engl J Med 2001; 345: 494-502.

6. Woulfe D, Yang J, Brass L. ADP and platelets: the end of the beginning. J Clin Invest 2001; 107: 1503-1505.
7. Schafer AI. Antiplatelet therapy. Am J Med 1996; 101: 199-209.

8. McNicol A, Israels SJ. Platelets and antiplatelet therapy. J Pharmacol Sci 2003; 93: 381-396.

9. Ruggeri ZM. Platelets in atherothrombosis. Nat Med 2002; 8: 1227-1234.

10. Kunapuli SP, Dorsam RT, Kim S, Quinton TM. Platelet purinergic receptors. Curr Opin Pharmacol 2003; 3: 175-180.

11. Conley PB, Delaney SM. Scientific and therapeutic insights into the role of the platelet $\mathrm{P} 2 \mathrm{Y} 12$ receptor in thrombosis. Current Opin Hematol 2003; 10: 333-338.

12. Clarke TA, Waskell LA. The metabolism of clopidogrel is catalyzed by human cytochrome P450 $3 \mathrm{~A}$ and is inhibited by atorvastatin. Drug Metab Dispos 2003; 31: 53-59.

13. Ding Z, Kim S, Dorsam RT, Jin J, Kunapuli SP. Inactivation of the human P2Y12 receptor by thiol reagents requires interaction with both extracellular cysteine residues, Cys17 and Cys270. Blood 2003; 101: 3908-3914.

14. Beckerath N, Taubert D, Pogatsa-Murray G, Schomig E, Kastrati A, Schomig A. Absorption, metabolization, and antiplatelet effects of 300, 600 and 900-mg loading doses of clopidogrel: results of the ISAR-CHOICE (intracoronary stenting and antithrombotic regimen: choose between 3 high oral doses for immediate clopidogrel effect) Trial. Circulation 2005; 112: 2946-2950.

15. Mega JL, Close SL, Wiviott SD, Shen L, Hockett RD, Brandt JT. Cytochrome P-450 polymorphisms and response to clopidogrel. N Engl J Med 2009; 360: 354-362.

16. Lee JM, Park S, Shin D-J, Choi D, Shim CY, Koy G et al. Relation to genetic polymorphisms in the cytochrome P450 gene with clopidogrel resistance after drug-eluting stent implantation in Koreans. Am J Cardiol 2009; 104: 46-51.

17. Brandt JC, Close SL, Iturria SJ, Payne CD, Farid NA, Ernest $\mathrm{CS}$ et al. Common polymorphisms of CYP2C19 and CYP2C9 affect the pharmacokinetic and pharmacodynamic response to clopidogrel but not prasugrel. J Thromb Haemost 2007; 5: 2429-2436.

18. Collet JP, Hulot JS, Pena A, Villard E, Esteve JV, Silvain J et al. Cytochrome P450 2C19 polymorphism in young patients treated with clopidogrel after myocardial infarction: a cohort study. Lancet 2009; 373: 309-317.

19. Sibbing D, Stegherr J, Latz W, Koch W, Mehili J, Dorrler K et al. Cytochrome P450 2C19 loss of function polymorphism and stent thrombosis following percutaneous coronary intervention. Eur Heart J 2009; 30: 916-922.

20. Thebault JJ, Kieffer G, Lowe GD, Nimmo WS, Cariou R. Repeated dose pharmacodynamics of clopidogrel in healthy subjects. Semin Thromb Hemost 1999; 25(Suppl 2): 9-14.

21. Thebault JJ, Kieffer G, Cariou R. Single-dose pharmaco- 
dynamics of clopidogrel. Semin Thromb Hemost 1999; 25(Suppl 2): 3-8.

22. Savcic M, Hauert J, Bachmann F, Wyld PJ, Geudelin B, Cariou $\mathrm{R}$ et al. Clopidogrel loading dose regimens: kinetic profile of pharmacodynamic response in healthy subjects. Semin Thromb Hemost 1999; 25(Suppl 2): 15-19.

23. Xiao Z, Theroux P. Clopidogrel inhibits platelet-leukocyte interactions and thrombin receptor agonist peptide-induced platelet activation in patients with an acute coronary syndrome. J Am Coll Cardiol 2004; 43: 1982-1987.

24. Lau WC, Gurbel PA, Watkins PB, Neer CJ, Hopp AS, Carville DG et al. Contribution of hepatic cytochrome P450 3A4 metabolic activity to the phenomenon of clopidogrel resistance. Circulation 2004; 109: 166-171.

25. Gilard M, Arnaud B, Le Gal G, Abgrall JF, Boschat J. Influence of omeprazole on the antiplatelet action of clopidogrel associated to aspirin. J Thromb Haemost 2006; 4: 2508-2509.

26. Cuisset T, Frere C, Quilici J, Poyet R, Gaborit B, Bali L et al. Comparison of omeprazole and pantoprazole influence on a high $150 \mathrm{mg}$ clopidogrel maintenance dose the PACA (proton pump inhibitors and clopidogrel association) prospective randomized study. J Am Coll Cardiol 2009; 54: 1149-1153.

27. Chong E, Ensom MHH. Pharmacogenetics of the proton pump inhibitors: a systematic review. Pharmacotherapy 2003; 23: 460-471.

28. Bhatt DL, Cryer B, Contant CF, Cohen M. The Cogent Trial. 2009. Available at: http://www.clinicaltrialresults.org/ Slides/TCT\%202009\%20Bhatt\%20COGENT\%20Press\%20 Conference.ppt. Accessed March 2010.

29. Lau WC, Waskell LA, Watkins PB, Gurbel PA, Neer CJ, Hopp AS. Atorvastatin reduces the ability of clopidogrel to inhibit platelet aggregation: a new drug-drug interaction. Circulation 2003; 107: 32-37.

30. Geisler T, Zurn C, Paterok M, Langer H, Bigalke B, Stellos $\mathrm{K}$ et al. Statins do not adversely affect post-interventional residual platelet aggregation and outcomes in patients undergoing coronary stenting treated by dual antiplatelet therapy. Eur Heart J 2008; 29: 1635-1643.

31. Gorchakova O, von Beckerath N, Gawaz M, Mocz A, Joost A, Schomig A et al. Antiplatelet effects of a $600 \mathrm{mg}$ loading dose of clopidogrel are not attenuated in patients receiving atorvastatin or simvastatin for at least 4 weeks prior to coronary artery stenting. Eur Heart J 2004; 25: 1898-1902.

32. Gurbel PA, Bliden KP, Hiatt BL, O' Connor CM. Clopidogrel for coronary stenting: response variability, drug resistance and the effect of pretreatment platelet reactivity. Circulation 2003; 107: 2908-2913.

33. Gurbel PA, Tantry US. Clopidogrel resistance? Thromb Res 2007; 120: 311-321.
34. Bonello I, Tantry US, Marcucci R, Blindt R, Gori AM, Paniccia $\mathrm{R}$ et al. Working Group on High On Treatment Platelet Reactivity. Consensus and future directions on the definition of high on-treatment platelet reactivity to adenosine diphosphate. J Am Coll Cardiol 2010; 56: 919-933.

35. Muller I, Besta F, Schulz C, Massberg S, Schonig A, Gawaz $\mathrm{M}$ et al. Prevalence of clopidogrel non-responders among patients with stable angina pectoris scheduled for elective coronary stent placement. Thromb Haemost 2003; 89: 783-787.

36. Mobley JE, Bresee SJ, Wortham DC, Craft RM, Snider CC, Carrolli R et al. Frequency of nonresponse antiplatelet activity of clopidogrel during pretreatment for cardiac catheterization. Am J Cardiol 2004; 93: 456-458.

37. Wiviott SD, Antman EM. Clopidogrel resistance: a new chapter in a fast moving story. Circulation 2009; 109: 3064-3067.

38. Angiolillo DJ, Fernandez-Ortiz A, Bernardo E, Ramierz CB, Sabate M, Fernandez $\mathrm{C}$ et al. Platelet aggregation according to body mass index in patients undergoing coronary stenting: should clopidogrel loading-dose be weight adjusted? J Invasive Cardiol 2004; 16: 169-174.

39. Paniccia R, Antonucci E, Maggini N, Priora R, Liotta A, Abbate R. Comparison of methods for monitoring residual platelet reactivity after clopidogrel by point-of-care tests on whole blood in high risk patients. Thromb Haemost 2010; 104: 287-292.

40. Gremmel T, Steiner S, Seidinger D, Koppensteiner R, Panzer S. Comparison of methods to evaluate clopidogrel-mediated platelet inhibition after percutaneous intervention with stent implantation. Thromb Haemost 2009; 101: 333-339.

41. Gurbel PA, Bliden KP, Samara W, Yoho JA, Hayes K, Fissha MZ. Clopidogrel effect on platelet reactivity in patients with stent thrombosis: results of the CREST Study. J Am Coll Cardiol 2005; 46: 1827-1832.

42. Labarthe B, Theroux P, Angio M, Ghitescu M. Matching the evaluation of the clinical efficacy of clopidogrel to platelet function tests relevant to the biological properties of the drug. J Am Coll Cardiol 2005; 46: 638-645.

43. Aleil B, Ravanat C, Cazenave JP, Rochoux G, Heitz A, Gachet C. Flow cytometric analysis of intraplatelet VASP phosphorylation for the detection of clopidogrel resistance in patients with ischemic cardiovascular diseases. J Thromb Haemost 2005; 3: 85-92.

44. Geiger J, Brich J, Honig-Liedl P, Eigenthaler M, Schnzenbacher P, Herbert JM et al. Specific impairment of human platelet $\mathrm{P} 2 \mathrm{Y}(\mathrm{AC}) \mathrm{ADP}$ receptor-mediated signaling by the antiplatelet drug clopidogrel. Arterioscler Thromb Vasc Biol 1999; 19: 2007-2011. 
45. Matetzky S, Shenkman B, Guetta V, Shechter M, Bienart R, Goldenberg I. Clopidogrel resistance is associated with increased risk of recurrent atherothrombotic events in patients with acute myocardial infarction. Circulation 2004; 109: 3171-3175.

46. Cuisset T, Frere C, Quilici J, Barbou F, Morange PE, Hovasse $\mathrm{T}$ et al. High post-treatment platelet reactivity identified low-responders to dual antiplatelet therapy at increased risk of recurrent cardiovascular events after stenting for acute coronary syndrome. J Thromb Haemost 2006; 4: 542-549.

47. Gurbel PA, Bliden KP, Guyer K, Cho PW, Zaman K, Kreutz $\mathrm{RP}$ et al. Platelet reactivity in patients and recurrent events post-stenting: results of the PREPARE POST-STENTING Study. J Am Coll Cardiol 2005; 46: 1820-1826.

48. Bliden KP, Tantry U, Zaman K, Bassi A, Hayes K, Yoho J et al. High platelet reactivity is a risk factor for post-discharge ischemic complications following elective coronary stenting. J Am Coll Cardiol 2005; 45: 33A.

49. Hochholzer W, Trenk D, Bestehorn HP, Fischer B, Valina $\mathrm{CM}$, Hocholzer $\mathrm{W}$ et al. Impact of the degree of periinterventional platelet inhibition after loading with clopidogrel on early clinical outcome of elective coronary stent placement. J Am Coll Cardiol 2006; 48: 1742-1750.

50. Barragan P, Bouvier JL, Roquebert PO, Macaluso G, Commeau P, Comet B et al. Resistance to thienopyridines: clinical detection of coronary stent thrombosis by monitoring of vasodilator-stimulated phosphoprotein phosphorylation. Catheter Cardiovasc Interv 2003; 59: 295-302.

51. Gurbel PA, Bliden KP, Zaman KA, Yoho JA, Hayes KM, Tantry US. Clopidogrel loading with eptifibatide to arrest the reactivity of platelets: results of the Clopidogrel Loading With Eptifibatide to Arrest the Reactivity of Platelets (CLEAR PLATELETS) study. Circulation 2005; 111: 1153-1159.

52. Lev EI, Patel RT, Maresh KJ, Guthikonda S, Granada J, Delao $\mathrm{T}$ et al. Aspirin and clopidogrel drug response in patients undergoing percutaneous coronary intervention: the role of dual drug resistance. J Am Coll Cardiol 2006; 47: 27-33.

53. Ajzenberg N, Aubry P, Huisse MG, Brummel KE, Paradis $\mathrm{SG}$, Butenas $\mathrm{S}$ et al. Enhanced shear induced platelet aggregation in patients who experience subacute stent thrombosis: a case control study. J Am Coll Cardiol 2005; 45: 1753-1756.

54. Marcucci R, Gori AM, Paniccia R, Marcucci R, Gori AM, Pannicia $\mathrm{R}$ et al. Cardiovascular death and nonfatal myocardial infarction in acute coronary syndrome patients receiving coronary stenting are predicted by residual platelet reactivity to ADP detected by a point-of-care assay: a 12-month follow-up. Circulation 2009; 119: 237-242.
55. Price MJ, Endemann S, Gollapudi RR, Valencia R, Stinis CT, Levisay JP et al. Prognostic significance of postclopidogrel platelet reactivity assessed by a point-of-care assay on thrombotic events after drug-eluting stent implantation. Eur Heart J 2008; 29: 992-1000.

56. Patti G, Nusca A, Mangiacapra F, Gatto L, D’ Ambrosio A, Di Sciascio G. Point of care measurement of clopidogrel responsiveness predicts clinical outcome in patients undergoing percutaneous coronary intervention: results of the ARMYDA-PRO (Antiplatelet therapy for reduction of myocardial damage during angioplasty-platelet reactivity predicts outcome) study. J Am Coll Cardiol 2008; 52: $1128-1133$.

57. Gurbel PA, Bliden KP, Hayes KM, Yoho JA , Herzog WR, Tantry US et al. The relation of dosing to clopidogrel responsiveness and the incidence of high post-treatment platelet aggregation in patients undergoing coronary stenting. J Am Coll Cardiol 2005; 45: 1392-1396.

58. Angiolillo DJ, Fernández-Ortiz A, Bernardo E, Ramierz C, Sabate M, Jimenez-Quevedo $\mathrm{P}$ et al. High clopidogrel loading dose during coronary stenting: effects on drug response and interindividual variability. Eur Heart J 2004; 25: 1903-1910.

59. Zider FJ, Moliternno DJ, Bhatt DL, Chew DP, Zidar FZ, Chan AW et al. High dose clopidogrel loading rapidly reduces both platelet inflammatory marker expression and aggregation. J Am Coll Cardiol 2004; 43: A64.

60. Muller I, Seyfarth M, Rudiger S, von Beckerath N, Taubert D, Pogatsa-Murray $\mathrm{G}$ et al. Effect of a high loading dose of clopidogrel on platelet function in patients undergoing coronary stent placement. Heart 2001; 85: 92-93.

61. Kastrati A, von Beckerath N, Joost A, Greenbaun AB, Grines CL, Bittl JA. Loading with $600 \mathrm{mg}$ clopidogrel in patients with coronary artery disease with and without chronic clopidogrel therapy. Circulation 2004; 110: 1916-1919.

62. Smith Jr SC, Feldman TE, Hirshfeld Jr JW, Jacobs AK, Kern MJ, King SB et al. (ACC/AHA/SCAI Writing Committee to Update 2001 Guidelines for Percutaneous Coronary Intervention). ACC/AHA/SCAI 2005 guideline update for percutaneous coronary intervention: a report of the American College of Cardiology/American Heart Association Task Force on Practice Guidelines. Circulation 2006; 113: e166-e286.

63. Bonello L, Camoin-Jau L, Arques S, Boyer C, Panagides D, Wittenberg $\mathrm{O}$ et al. Adjusted clopidogrel loading doses according to vasodilator-stimulated phosphoprotein phosphorylation index decrease rate of major adverse cardiovascular events in patients with clopidogrel resistance: a multicenter randomized prospective study. J Am Coll Cardiol 2008; 51: 1404-1411.

64. Wiviott SD, Trenk D, Frelinger AL, O' Donoghue M, Neumann FJ, Michelson AD et al. Prasugrel compared with 
high loading- and maintenance-dose clopidogrel in patients with planned percutaneous coronary intervention: the prasugrel in comparison to clopidogrel for inhibition of platelet activation and aggregation-thrombolysis in Myocardial Infarction 44 trial. Circulation 2007; 116: 2923-2932.

65. Montalescot G. Assessment of the best loading dose of clopidogrel to blunt platelet activation, inflammation and ongoing necrosis (ALBION) trial. In: Euro PCR. Paris, France: 2005.

66. Di Sciascio G, for the ARMYDA-4 Investigators ARMYDA4 (Antiplatelet therapy for reduction of myocardial damage during angioplasty) study. Prospective, multicenter, randomized, double blind trial investigating influence on PCI outcome of additional $600 \mathrm{mg}$ clopidogrel load in patients on chronic therapy-ARMYDA-RELOAD. Presented at: Transcatheter Cardiovascular Therapeutics (TCT); 2007, October 23; Washington, DC.

67. Di Sciascio G, for the ARMYDA-5 Investigators ARMYDA5 (Antiplatelet therapy for reduction of myocardial damage during angioplasty) study. Prospective, multicenter, randomized trial investigating influence on outcome of inlab $600 \mathrm{mg}$ clopidogrel loading vs. 6-hour prePCI treatment-ARMYDA-Preload. Presented at: Transcatheter Cardiovascular Therapeutics (TCT); 2007, October 23; Washington, DC.

68. Varenhorst C, James S, Erlinge D, Braun OO, Man M, Siegbahn A, Walker J et al. Genetic variation of CYP2C19 affects both pharmacokinetic and pharmacodynamic responses to clopidogrel but not prasugrel in aspirin-treated patients with coronary artery disease. Eur Heart J 2009; 30: 1744-1752.

69. Jernberg T, Payne CD, Winters KJ, Darstein C, Brandt JT, Jakubowski et al. Prasugrel achieves greater inhibition of platelet aggregation and a lower rate of non-responders compared with clopidogrel in aspirin-treated patients with stable coronary artery disease. Eur Heart J 2006; 27: 1166-1173.

70. Jakubowski JA, Payne CD, Brandt JT, Suh JW, Koo BK, Zhang SY et al. The platelet inhibitory effects and pharmacokinetics of prasugrel after administration of loading and maintenance doses in healthy subjects. J Cardiovasc Pharmacol 2006; 47: 377-384.

71. Montalescot G, Sideris G, Cohen R, Meuleman C, BalditSollier C, Barthelemy O et al. Prasugrel compared with high-dose clopidogrel in acute coronary syndrome. Thromb Haemost 2010; 103: 213-223.
72. Wiviott SD, Antman EM, Winters KJ, Weerakkody G, Murphy SA, Behounek BD et al. JUMBO-TIMI 26 Investigators. Randomized comparison of prasugrel (CS747, LY640315), a novel thioenopyridine P2Y12 antagonist, with clopidogrel in percutaneous coronary intervention: results of the Joint Utilization of Medications to Block Platelets Optimally (JUMBO)-TIMI 26 trial. Circulation 2005; 28(111): 3366-3373.

73. Wiviott SD, Braunwald E, McCabe $\mathrm{CH}$. Prasugrel versus clopidogrel in patients with acute coronary syndromes. N Engl J Med 2007; 357: 2001-2015. doi: 10.1056/NEJM Moa 0706482.

74. Storey F. P2Y12 receptors as a therapeutic agent in cardiovascular disease. Platelets 2001; 12: 197-209.

75. Storey RF, Wilcox RG, Heptinstall S. Comparison of the pharmacodynamic effects of the platelet ADP receptor antagonists clopidogrel and AR-C69931MX in patients with ischemic heart disease. Platelets 2002; 13: 407-413.

76. Kim J-Y, Lee K, Shin M, Ahn M, Choe H, Yoo BS et al. Cilostazole could ameliorate platelet responsiveness to clopidogrel in patients undergoing primary percutaneous coronary intervention. Circ J 2007; 71: 1867-1872.

77. Jeong Y-H, Lee S-W, Choi B-R, Kim I-S, Seo M-K, Kwak $\mathrm{C}-\mathrm{H}$ et al. Randomized comparison of adjunctive cilostazole versus high maintenance dose clopidogrel in patients with high post-treatment platelet reactivity: results of the ACCEL-RESISTANCE (Adjunctive cilostazole versus high maintenance dose clopidogrel in patients with clopidogrel resistance) randomized study. J Am Coll Cardiol 2009; 53: 1101-1119.

78. Husted S, Enanuelsson H, Heptinstall S, Sandset PM, Wickens M, Peters G. Pharmacodynamics, pharmacokinetics, and safety of the oral reversible P2Y12 antagonist AZD6140 with aspirin in patients with atherosclerosis: a double blind comparison to clopidogrel with aspirin. Eur Heart J 2006; 27: 1038-1047.

79. Wallentin L, Becker RC, Budaj A, Cannon CP, Emanuelsson $\mathrm{H}$, Held $\mathrm{C}$ et al. Ticogrelor versus clopidogrel in patients with acute coronary syndrome. N Engl J Med 2009; 361: 1045-1057.

80. Bhatt DL, Lincoff AM, Gibson CM, Granger CB, Alexander $\mathrm{JH}$, McMurray JJC et al. Intravenous platelet blockade with cangrelor in patients undergoing PCI. N Engl J Med 2009; 361: 2330-2341.

81. Harrington RA, Stone GW, McNutly S, White HD, Lincoff $\mathrm{AM}$, Gibson CM et al. Platelet inhibition with cangrelor in patients undergoing PCI. N Engl J Med 2009; 361: $2318-2329$. 